\title{
WOOD STRUCTURE, XYLEM FUNCTIONALITY AND GROWTH OF SIX SALIX CLONES IN TWO SITES WITH DIFFERENT ENVIRONMENTAL STRESS IN ARGENTINA ${ }^{1}$
}

\author{
Sabrina Anahí Loval², Teresa Cerrillo², Eleana Spavento³, Gonzalo Caballé ${ }^{4}$, Alejandro Martinez Meier ${ }^{4}$ \\ and Silvia Monteoliva ${ }^{5^{*}}$
}

\footnotetext{
${ }^{1}$ Received on 14.12.2017 accepted for publication on 24.04.2018.

${ }^{2}$ Instituto Nacional de Tecnologia Agropecuaria, EEA Delta del Paraná, Campana, Buenos Aires, Argentina. E-mail: <loval.sabrina@inta.gob.ar> and <cerrillo.teresa@inta.gob.ar>.

${ }^{3}$ Universidad Nacional de La Plata, Laboratorio de Investigaciones en Madera, La Plata, Buenos Aires, Argentina. E-mail: <eleanaspavento@yahoo.com.ar>.

${ }^{4}$ Instituto Nacional de Tecnologia Agropecuaria, EEA Bariloche, Rio Negro, Argentina. E-mail: <caballe.gonzalo@inta.gob.ar>. and $<$ saldungary@hotmail.com>.

${ }^{5}$ Universidad Nacional de La Plata,Instituto de Fisiologia Vegetal, La Plata, Buenos Aires, Argentina. E-mail: <smonteoliva@yahoo.com.ar>.

*Corresponding author.
}

ABSTRACT - The aims of the study were to evaluate the effects of abiotic stress (plantation site) and genotype (clone) on the wood anatomy and density of six Salix (willow) clones at three ages (2, 7, and 12 years), and the impact of these effects on the theoretical xylem hydraulic conductivity (Ks) and growth. The clones studied were 'Ragonese 131-25 INTA', 'Ragonese 131-27 INTA' and "250-33" (originated from crosses between Salix babylonica and S. alba), 'Barrett 13-44 INTA' and "NZ 26992" (originated from crosses between $S$. matsudana and $S . a l b a$ ), and the clone $S$. babylonica var. sacramenta 'Soveny Americano'. They were planted in two sites of the province of Buenos Aires, Argentina, with different abiotic stress: i) the Paraná River Delta, a site with recurrent floods, and ii) a continental site with lower water availability and no floods. The vessel morphometry, wood density, Ks, and current annual increments at the three ages were determined. The clone $\mathrm{x}$ site interaction was the source of variation with greatest impact, being this significant for vessel diameter, Ks, wood density and growth. This means that, depending on the type of stress at the plantation site, the clones responded differently, showing differences in their structure, functionality, and wood production. The results showed that the clones Soveny Americano and 26992 were better suited to stress by flood, whereas clones 131-25, 131-27, 250-33 and 13-44 were better adapted to moderate drought conditions, with responses at the level of the xylem and wood density, and therefore at the level of wood production.

Keywords: Wood Anatomy; Flood; Hydraulic conductivity.

\section{ESTRUTURA DO XILEMA, FUNCIONALIDADE E CRESCIMENTO DE SEIS CLONES DE SALIX EM RELAÇÃO COM DOIS SÍTIOS COM DIFERENTE ESTRESSE AMBIENTAL NA ARGENTINA}

\begin{abstract}
RESUMO-Os objetivos do trabalho foram: 1-determinar o efeito do estresse hídrico (sitios de implantação) e do genótipo (clone) na anatomia e densidade da madeira produzida em seis clones de salgueiros em três idades; 2 - verificar como essas variações na anatomia impactam na condutividade hidráulica teórica do xilema (Ks) e no crescimento. Foram mostrados seis clones, de 13 anos de idade de origem do cruzamento Salix babylonica $x$ S. alba (Ragonese INTA 131-25, 131-27 e 250-33), S. matsudana $x$ S. alba (Barrett 13-44 e NZ 26992) e S. babylonica var sacramenta 'Soveny Americano' implantados em duas situações com diferente estresse abiótico (sítio DM Delta Del Río Paraná com inundações recorrentes e sítio LH zona continental província de Buenos Aires, com menor disponibilidade da água e sem inundações). Foi determinado: morfometria dos vasos, densidade da madeira, Ks e incrementos correntes anuais em três idades (2, 7 e 12 anos). A interação clone x sítio foi a fonte de variação que maior impacto teve nas variáveis e foi significante
\end{abstract}


para o diâmetro de vasos, densidade, Ks e crescimentos. Isso significa que dependendo do tipo de estresse sofrido no sítio de implantação, os clones respondem de maneira diferente em sua estrutura, funcionalidade e produção da madeira. Existem clones melhor adaptados ao estresse por inundação (americano e 26992) e outros mais adaptados nas condições moderadas de seca (131-25, 131-27, 250-33 e 13-44), obtendo respostas no nível do xilema, densidade e, portanto, a produção da madeira.

Palavras-Chave: Anatomia Madeira,Inundação, Condutividade hidráulica

\section{INTRODUCTION}

Willows (Salix spp.) have advantages that allow them to be used as model systems for forest studies. These advantages include rapid growth, ease of cloning, and good correlation between their morpho-physiological characteristics and biomass production. The Delta of the Paraná River, Argentina, currently has 83,370 ha forested with willows, a fact that makes these forests third in importance (10.3\%) after pine and eucalyptus ones (Borodowski et al., 2014). In this region of the Delta, prolonged floods affect the productivity of most species. However, since willows show greater tolerance to prolonged flooding periods, an attribute that varies according to the species and clone, they are better suited than other trees such as poplar trees (Cerrillo et al., 2014; Doffo et al., 2017; Quiñones et al., 2017).

The increase in the abiotic stress caused by the climate change presents the great challenge of maintaining the productive efficiency and the capacity of response to extreme weather events. In the past 50 years, the average temperature in Argentina has increased between 0.5 and $1{ }^{\circ} \mathrm{C}$ (Villalba et al., 2012), whereas the mean flows of the rivers of the Paraná-Río de la Plata Basin have increased by $35 \%$. The most important climatic factor linked to this increase in the river flows is the average annual rainfall and its seasonal and regional distribution (Barros, 2013). In the case of the Paraná River, sensitivity studies suggest that, in a warmer setting, the flows would increase by $25 \%$ (Barros, 2013). In the region of the Delta, this increase is expected to lead to water excess during the winter, with greater frequency and impact of floods, and to water deficit during the summer.

Wood fulfils functions of water transport and storage, essential for the survival of woody species facing environmental variations. Wood density, an emergent property of the anatomical characteristics of wood (cell walls and lumen percentages), is mainly related to the possibilities of water conduction in the xylem (Ziemińska et al., 2015; Barotto et al., 2017), but is also a variable of great technological value (Walker,
2006). The functional adjustments of individuals to abiotic stressors can be interpreted from the study of the base properties of wood (anatomy and density) and their relationships to the multiple processes in which wood is involved (Zanne et al., 2010).

Based on the above, the present study focused on evaluating the variability and adaptability of different Salix clones, under the hypothesis that they show a plastic response that can be studied from their structuralvascular anatomy and wood density characters, which are related to physiological responses to environmental stress that condition plant growth and the technological aptitude of wood. Thus, the aims of the study were: 1 - to determine the effects of abiotic stress (plantation site) and genotype (clone) on wood anatomy and density at three moments of the ontogeny of the tree (three ages) within a normal cycle of the forest production of Salix (13 years), and 2- to test how variations in the anatomy impact on the theoretical xylem hydraulic conductivity and the growth of plants.

\section{MATERIALS AND METHODS}

Wood samples were collected from six Salix clones: three originated from crosses between Salix babylonica and $S$. alba ('Ragonese INTA 131-25', 'Ragonese INTA 131-27', and '250-33"), two originated from crosses between S. matsudana and S. alba ('Barrett 13-44 INTA' and "NZ 26992"), and the clone S. babylonica var sacramenta 'Soveny Americano' (hereinafter American, a clone occupying the largest area of plantations of Salix spp in the Paraná River Delta). All the material belongs to clones planted in 1987, with a distance of $3 \mathrm{~m}$ between rows and $2 \mathrm{~m}$ between plants, in two sites with similar climatic characteristics, but with particular situations of environmental stress (see below). The growth period of the trees corresponded to the years 1988-2001 (13 years at the time of sampling), and the wood samples were analyzed at three different ages: 2, 7 and 12 years of age (i.e. in 1990, 1995 and 2000, respectively).

Revista Árvore. 2018;42(1):e420110 
Site LH: Los Hornos $\left(34^{\circ} 55^{\prime} \mathrm{S}, 57^{\circ} 57^{\prime} \mathrm{W} ; 5 \mathrm{~m}\right.$ above sea level): this site is representative of the continental zone of the province of Buenos Aires, and corresponds to plantations developed on soils identified as Typic Argiudoll, fine, illitic, thermal, with an abrupt textural change at $50 \mathrm{~cm}$, which can be considered as a drainage impediment. The maximum average temperature during the study period was $22.8^{\circ} \mathrm{C}$, whereas the minimum average temperature was $9.4^{\circ} \mathrm{C}$. The mean annual precipitation was $1143.5 \mathrm{~mm}$, with an isohydric regime. Of the three years analyzed in the present study (1990, 1995 and 2000), 1995 was the one with highest maximum temperatures and minimum rainfall during the plant growth period (August -March) (Fig. 1, left). Thus, 1995 (planting age: 7 years) can be referred to as the year with greatest water deficit.

Site DM: Paraná River Delta, Arroyo Martínez, Ibicuy Islands, Entre Ríos province ( $33^{\circ} 45^{\prime} \mathrm{S} ; 59^{\circ}$ $05^{\prime} \mathrm{W} ; 1 \mathrm{~m}$ above sea level): this site corresponds to plantations developed on systematized Hydroquent soils protected from flood by dams. During the study period, there were three extraordinary flood events of the Paraná River: an episode of 4 months (MayAugust 1992, plantation age: 4 years), a quick and short period of 2 months (March-April 1997, plantation age: 9 years), and a long period of 7 months (January-July 1998, plantation age: 10 years) (Baigun et al., 2008;
García et al., 2011; Cerrillo et al., 2013). The levels of the Paraná River were high during the first two years analyzed (1990 and 1995) and low in the third year analyzed (2000) (Fig. 1, right). Average maximum and minimum annual temperature and precipitation values in this site were similar to those of the continental site $\left(22.5^{\circ} \mathrm{C}, 11.2^{\circ} \mathrm{C}\right.$, and $1220 \mathrm{~mm}$ with isohydric regime, respectively), and 1995 was identified as the year with highest maximum temperatures and minimum precipitation (Fig. 1, left). However, unlike that observed in site LH, it is not possible to assert that 1995 was a year with water deficit in site DM. In contrast, 1992 and 1998 (plantation ages: 4 and 10 years respectively) were identified as the years of greatest water stress by flooding, although the flood event in 1998 was longer and involved part of the growth period of the trees, thus showing a greater impact on their growth.

Site LH can thus be characterized as a site with lower stress due to water excess during the study period because water availability was generally at "field capacity", and was a site that suffered water deficit only in spring-summer of 1995. Comparatively, site DM maintained higher water availability throughout the study period, but suffered two significant pulses of flood stress in the years inbetween the years sampled.
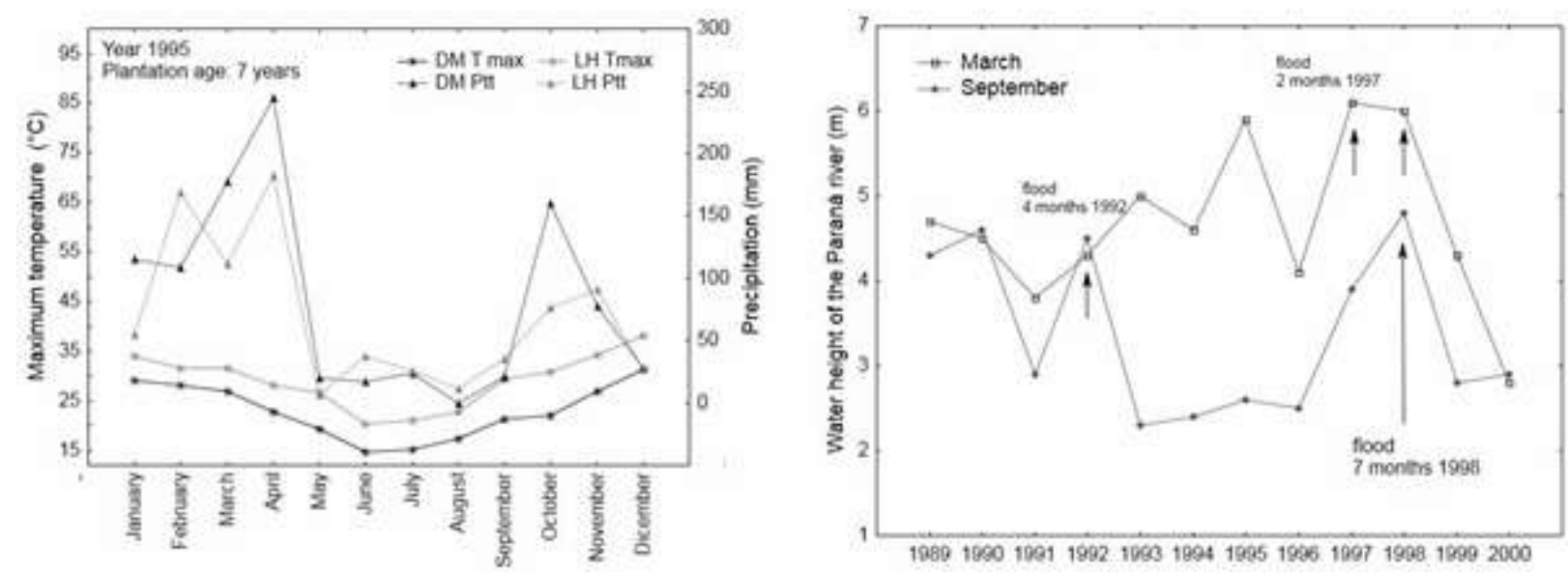

Figure 1 - Left: Monthly maximum temperature values (T max) and precipitation (Ptt) in both sites for 1995 (plantation age: 7 years). Right: Height values of the Paraná River in the years studied.

Figura 1 - Esquerda: valores mensuales de temperaturas máximas (T máx.) e precipitação (Ptt) em ambos sítios para o ano 1995 (Idade de plantação 7 anos). Direita: valores de atura do Rio Paraná durante os anos calendário do ensaio. 
Five trees per clone were selected at each site. Their diameter at breast height $(\mathrm{DBH}-1.3 \mathrm{~m}$ of the soil) was measured with dendrometric tape, and their total height determined with tape measure. Two successive destructive samples (5-cm-thick slices) were taken from the shaft at a height of $1.30 \mathrm{~m}$ and then debarked. Then, a central piece of each slice $(3 \mathrm{~cm}$ wide and of the height of the slice) was cut from bark to bark, including the pith. After polishing the pieces, the growth rings were marked and measured on both radii (opposite) with a binocular magnifier ( $\mathrm{mm}$ ). The width of the rings was used to estimate the individual basal area $\left(\mathrm{cm}^{2}\right)$, to obtain the mean current annual increments (CAI), which, according to Levy and Mckay (2003), are better estimators of plant vigor.

Three radial positions were identified (ages: 2 , 7 and 12 years), which allowed knowing the variation according to the ontogeny of the tree. Two samples per tree were used for each age studied, totaling 60 samples per clone ( 2 samples x 5 trees x 3 ages x 2 sites) and 360 total samples (60 samples/clone $\mathrm{x} 6$ clones).

The morphometry of the vessels (mean diameter of the lumen in $\mu \mathrm{m}$ and number of vessels per $\mathrm{mm}^{2}$ ) was measured on histological cuts made with a sliding microtome, on the three radial positions established. The samples were dyed with safranin and observed with an optical microscope (CX31 Olympus, Japan). Digital images were obtained with a Lumenera camera (Canada) to perform measurements with specific software (Image Pro, Media Cybernetics, USA).

The basic density of the wood $\left(\mathrm{g} / \mathrm{cm}^{3}\right)$ in all the samples was determined as the quotient between the anhydrous weight and the green volume.

The theoretical xylem hydraulic conductivity (Ks, $\mathrm{kg} / \mathrm{m} \mathrm{MPa} \cdot \mathrm{s})$ was estimated with the Hagen Poiseuille law:

$$
K s=\frac{\left[\left(\pi \rho d^{4}\right) / \eta\right]}{128 \cdot N}
$$

where $\rho$ is the water density $\left(\mathrm{kg} / \mathrm{m}^{3}\right), \eta$ is the diameter of the vessel lumen $(\mathrm{m}), c ̧$ is the water viscosity (MPa.s) and $N$ is the number of vessels per $\mathrm{m}^{2}$.

Measures of central tendency and dispersion were calculated, and graphical and analytical tools were used to determine the normality of the distribution of the variables. The values obtained were analyzed and

Revista Árvore. 2018;42(1):e420110 compared through analysis of variance and Tukey's multiple comparison test $(\mathrm{p}<0.05)$. The clone (six levels), site (two levels) and age (three levels) were taken as sources of variation (fixed effects). Only double interactions were taken into account. The height and DBH were evaluated at 13 years of age, for which the sources of variation of the fixed effects model were reduced to site and clone and the site $\mathrm{x}$ clone interaction. Pearson correlations were performed to establish associations between variables $(p<0.1)$.

\section{RESULTS}

\section{Vessel anatomy, hydraulic conductivity and wood density variation}

Vessel diameter and wood density showed significant differences due to the site, clone and site $\mathrm{x}$ clone interaction $(\mathrm{p}=0.001, \mathrm{p}=0.02$ and $\mathrm{p}=0.004$, respectively, for vessel diameter and $\mathrm{p}=0.002, \mathrm{p}=$ 0.000 and $p=0.020$, respectively, for wood density). The hydraulic conductivity of the xylem was significantly influenced only by the clone $\mathrm{x}$ site interaction $(\mathrm{p}=$ $0.05)$. The number of vessels presented no significant variations with any of the effects tested $(\mathrm{p}>0.05)$ (Fig. 2 ). Neither the age of the sample nor its interactions were significant with any of the variables evaluated $(\mathrm{p}>0.05)$.

The diameter of the vessels ranged from 53 to 91 $\mu \mathrm{m}$ depending on the clone and site (Fig. 2). The average value in site DM was significantly lower $(65 \pm 9 \mu \mathrm{m})$ than in site LH $(74 \pm 8 \mu \mathrm{m})$. The lowest value was obtained by clone 131-27 in site LH, whereas the largest value was obtained by the American Willow in site DM. All the clones, except for the American Willow, presented smaller vessel diameters in site DM than in site LH (Fig. 2 ). The variation in the number of vessels ranged from 35 to 91 vessels per $\mathrm{mm}^{2}$. Although there was a tendency to a higher number of vessels in site DM, in the case of some clones such as 131-27, 250-33 and 26992, this increase was not significant at the level of the site, not even the effects of the interaction, which could be masking the main effects of the site, clone and age. The theoretical xylem hydraulic conductivity followed the same trend as the diameter of the vessels: it varied from 12 to 55 $\mathrm{Kg} / \mathrm{m} \mathrm{MPa} \cdot \mathrm{s}$ depending on the clone and site (Fig. 2). The lowest value was that of clone 131-27 in site LH, whereas the largest value was that of the American clone in site DM. The wood density was significantly lower in site DM $\left(0.392 \pm 0.02 \mathrm{~g} / \mathrm{cm}^{3}\right)$ than in site LH $(0.403$ 

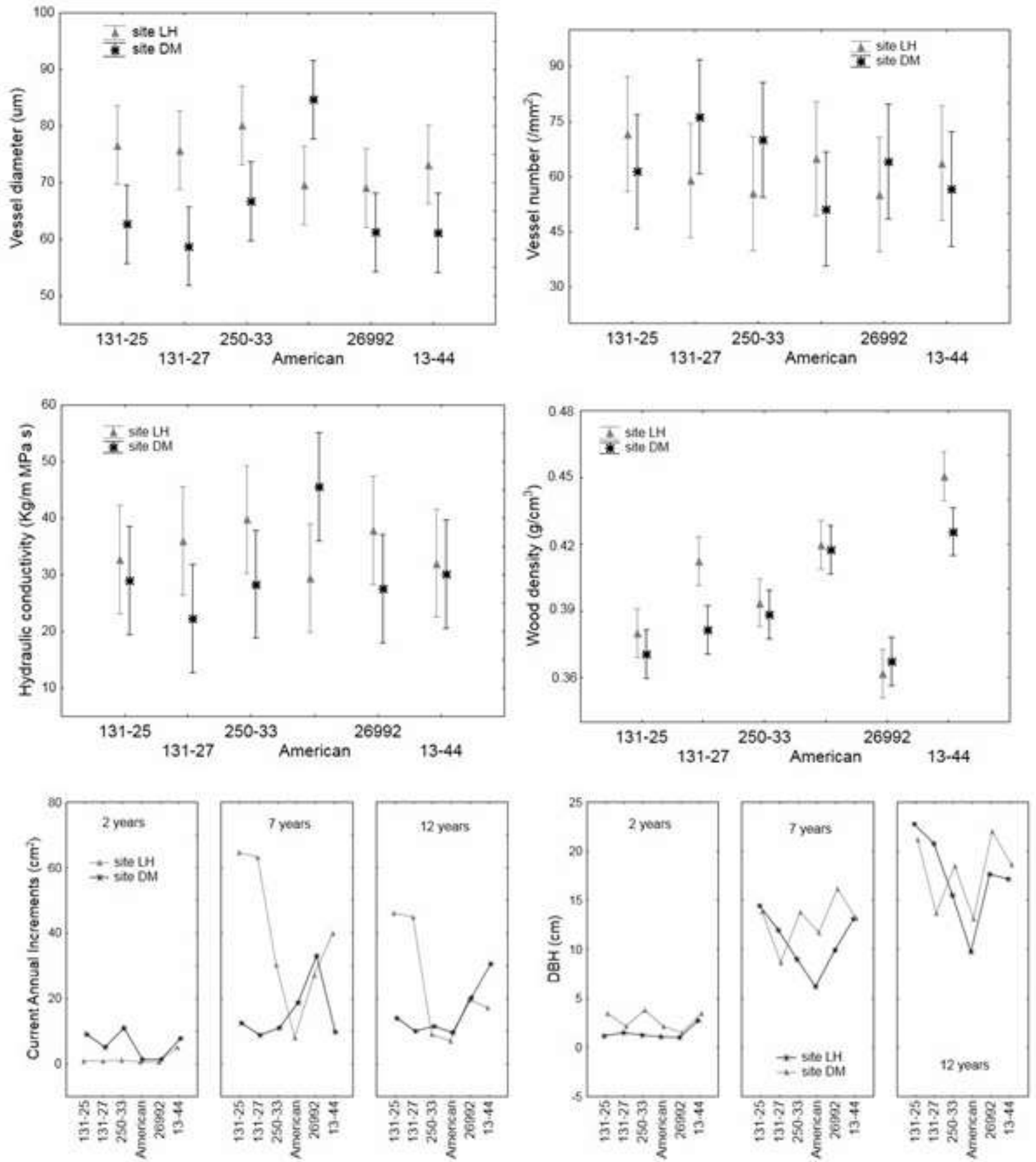

Figure 2 - Variability (clonal mean \pm deviation) of the vessel diameter, number of vessels, theoretical xylem hydraulic conductivity, and wood density, discriminated by clone and site. Diameter at breast height (DBH) and current annual increments per clone, site and age.

Figura 2 - Variabilidade (média clonal \pm desvio) dos diâmetros e números de vasos. da condutividade hidráulica teórica do xilema e da densidade básica da madeira. discriminados por clone e sítio. Diâmetro altura do peito $(D A P)$ e incrementos correntes anuais por clone. sítio e idade. 
Table 1 - Average growth considering total height and diameter at breast height with bark (DBH w/b) for all the clones studied in both sites at harvest age (13 years).

Tabela 1-Crescimento médio em altura total e diâmetro altura do peito (DAP c/c) com cortiça para em ambos sítios da idade de colheita (13 anos)

\begin{tabular}{|c|c|c|c|c|c|}
\hline \multirow[t]{2}{*}{ Crossing } & \multirow[b]{2}{*}{ Clone } & \multicolumn{2}{|c|}{ Site LH } & \multicolumn{2}{|c|}{ Site DM } \\
\hline & & Total height $(\mathrm{m})$ & $\mathrm{DBH} w / \mathrm{b}(\mathrm{cm})$ & Total height $(\mathrm{m})$ & $\mathrm{DBH} w / \mathrm{b}(\mathrm{cm})$ \\
\hline \multirow{3}{*}{ S. babylonica x S. alba } & $131-25$ & $14.2 \mathrm{bc} \mathrm{A}$ & $22.76 \mathrm{~d} \mathrm{~A}$ & $18.7 \mathrm{bcB}$ & $21.24 \mathrm{~b} \mathrm{~A}$ \\
\hline & $131-27$ & 14.8 c $\mathrm{A}$ & $20.80 \mathrm{cdB}$ & 14.7 a A & 13.69 a A \\
\hline & $250-33$ & $13.0 \mathrm{~b} \mathrm{~A}$ & $15.56 \mathrm{~b} \mathrm{~A}$ & 18.9 c B & $18.46 \mathrm{~b} \mathrm{~B}$ \\
\hline S. babylonica & American & 10.7 a A & 9.79 a A & $16.2 \mathrm{abB}$ & $13.12 \mathrm{a} \mathrm{B}$ \\
\hline \multirow[t]{2}{*}{ S. matsudana x S. alba } & 26992 & $12.6 \mathrm{~b} \mathrm{~A}$ & $17.69 \mathrm{bcA}$ & 19.8 c B & $22.08 \mathrm{~b} \mathrm{~B}$ \\
\hline & $13-44$ & $13.4 \mathrm{bc} \mathrm{A}$ & $17.14 \mathrm{bcA}$ & $18.2 \mathrm{bcB}$ & $18.65 \mathrm{~b} \mathrm{~A}$ \\
\hline
\end{tabular}

The lowercase letters are read vertically for each variable between clones, whereas uppercases are read horizontally for each variable between sites, and indicate significant differences according to Tukey's test $(\mathrm{p}<0.05)$.

$\pm 0.03 \mathrm{~g} / \mathrm{cm}^{3}$ ), ranging between 0.352 and $0.461 \mathrm{~g} / \mathrm{cm}^{3}$ (Fig. 2), with significant differences according to the clone $\mathrm{x}$ site interaction. The lowest average density was that of clone 26992 in site $\mathrm{LH}$, whereas the highest value was that of clone 13-44, in the same site.

\section{Growth}

The different structural responses of the clones against abiotic stress at the level of the xylem in the two sites were reflected in the tree growth attained regarding both height and diameter $(\mathrm{DBH})$ (Table 1, Fig. 2) as well as in the CAI (Fig. 2).

At 13 years of age, both tree height and $\mathrm{DBH}$ showed significant differences due to the clone $\mathrm{x}$ site interaction. The overall height was significantly higher in site DM $(17.75 \pm 1.9 \mathrm{~m})$ than in site $\mathrm{LH}(13.75 \pm 1.4 \mathrm{~m})$ (Table 1), whereas DBH showed no differences between sites. Three of the clones (250-33, American, and 26992) showed a significantly higher DBH in site DM than in site LH, whereas clones 131-25 and 13-44 showed a similar DBH in both sites, and clone 131-27 showed a significantly lower DBH in site DM than in site LH. The American Willow was the clone with slowest growth regarding both height and DBH in both sites (Table 1).

The CAI were significantly different depending on the site, clone and age analyzed, as well as on their interactions (Fig. 2). In site LH, all the clones, except clone 13-44, presented low CAI and no significant differences in the younger age (2 years). However, at 7 years of age, all the clones presented maximum wood production and significantly different from each other, being clones 131-25, 131-27 and 13-44 the most

Revista Árvore. 2018;42(1):e420110 outstanding ones. At 12 years of age, all the clones significantly decreased their CAI with respect to 7 years of age. The highest values were those of clones 131 25 and 131-27 (Fig. 2).

The American Willow was the clone with slowest growth at all ages, also reflected by the DBH with bark (Table 1). In site DM, at 2 years of age, clones 26992 and American had significantly lower CAI than the rest of the clones. On the other hand, at 7 years of age, this trend was reversed, being clone 26992 the one with greatest wood production, followed by the American (Fig. 2). The CAI values of the other four clones were low and presented no significant differences with regard to the earlier age. It should be noted that, at 4 years of age (1992), the trees in this site (site DM) suffered a period of 4 months of floods (see the Materials and Methods section). At 12 years of age, clone 1344 was the only one that significantly increased its growth in basal area. Clones 131-25, 131-27 and 25033 remained unchanged, while clone 26992 and American significantly decreased their CAI with respect to 7 years of age (Fig. 2).

The measurements at 12 years of age in site DM reflected, to some extent, the stress due to the floods suffered by the trees at 10 years of age ( 7 months of duration). Clones 26992 and 13-44 were the ones whichmaintained agood wood production after the long period of stress by floods.

\section{Relationship between growth and the structural and functional variables of the xylem}

The correlations of means between variables, considering clones and sites together $(n=36)$, showed significant relationships only between the CAI and 
hydraulic conductivity $(\mathrm{Ks})(\mathrm{r}=0.34)$ and vessel diameter $(\mathrm{r}=0.38)$ (Fig. 3). There was no significant relationship between Ks and wood density, or wood density and growth. When discriminating the data by age $(n=12)$, the maximal theoretical Ks of the clones in both sites explained $51 \%$ of the CAI reached at 7 years of age (Fig. 3), whereas vessel diameter was also positively related to the CAI $(r=0.59)$. Wood density and Ks showed a correlation, which was positive at two years of age, negative at 7 years of age and not significant at 12 years of age. The separation of the data by site $(n=18)$ allowed finding significant correlations between vessel diameter and growth $(r=0.51, p=0.03$ with CAI) for site LH. In site DM, wood density was positively correlated with Ks (Fig. 3).

\section{DISCUSSION}

\section{Vessel anatomy, hydraulic conductivity and wood} density variations

The significant clone $\mathrm{x}$ site interaction in the xylem variables analyzed, i.e. vessel diameter, Ks and wood
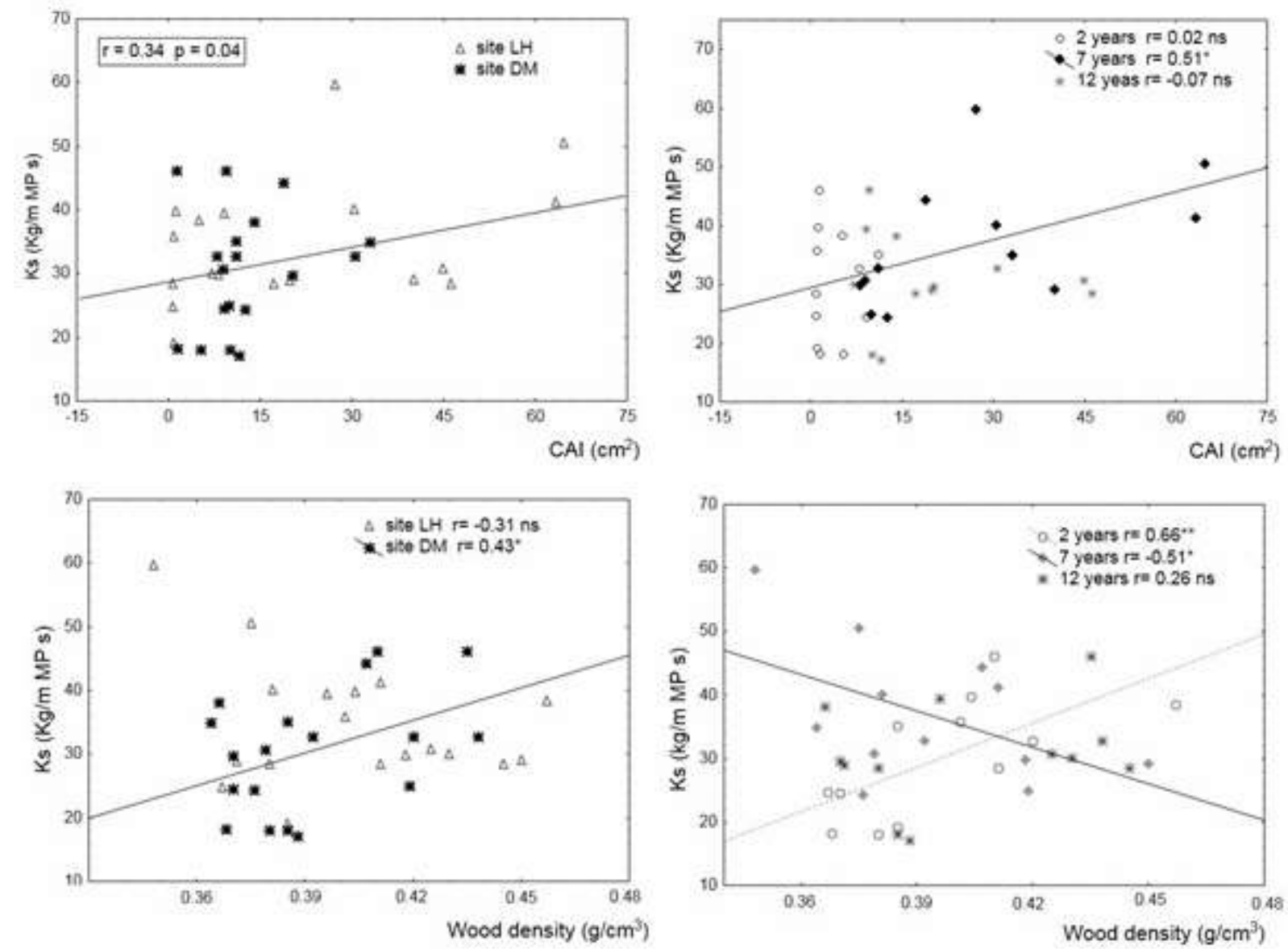

Figure 3 - Pearson correlations between theoretical xylem hydraulic conductivity (Ks) vs. current annual increments (CAI) and basic wood density. Up and left: set of all data $(n=36)$, above right: discriminated by age $(n=12)$, down left: discriminated by site $(\mathrm{n}=18)$, down right: discriminated by age $(\mathrm{n}=12)$.

Figura 3 - Correlações de Pearson entre condutividade hidráulica teórica do xilema (Ks) em relação incrementos corrente anuais (ICA) e densidade básica da madeira. Acima esquerda: conjunto de todos os dados $(n=36)$, acima direita: discriminados por idade $(n=12)$, abaixo esquerda: discriminados por sitio $(n=18)$, abaixo direita: discriminados por idade $(n=12)$. 
density, seem to indicate that, from the functional and structural points of view, the clones studied show a differential response depending on the type of stress imposed by the plantation site (Fichot et al., 2009; Schreiber et al., 2011; Copini et al., 2016; Doffo et al., 2017; Quiñones et al., 2017). Previous works have studied the effects of the plantation site, the genetic origin and the clone on wood density of poplar trees in the province of Buenos Aires and the Paraná River Delta (Monteoliva and Senisterra, 2008). Also, partial studies have been performed on the variation in wood density and anatomy in willows depending on the clone, both in the Delta region and in continental sites of the province of Buenos Aires (Monteoliva and Marlats, 2007; Monteoliva and Cerrillo, 2013; Cerrillo et al., 2016). The results of these studies showed the impacts of the plantation site and of the different (traditional and new) crosses on the wood density and anatomical structure, as well as on the end uses of the wood. However, since these results showed no associations between the hydraulic and structural properties of the wood of different Salix species/clones, it is not possible to select genotypes with desirable technological features without conditioning their capacity of response against an increase in the abiotic stress.

Since the present study corresponds to a longterm field experiment, it has some limitations, such as the fact that there was no control of the variation in the abiotic stressors and that, consequently, the responses could not be quantified clearly. However, in the study period (1988-2001), during which the monthly temperatures and precipitation in both sites were similar, site DM suffered water stress by excess (flood) (in three clearly identifiable events) (Fig. 1), whereas site LH did not. In turn, due to the type of soil, site LH generally maintained the availability of water to "field capacity", although this site is prone to water stress by drought, especially in dry summers, but without problems of temporary flood or sodicity. In this sense, site LH could be characterized as the site of less stress by water excess during the study period and as the one that, in general, maintained its water availability to "field capacity", with possible water shortage in spring and summer of 1995 (Fig. 1). Comparatively, site DM maintained higher water availability during the study period, but presented two major pulses of stress by flood in 1992 and 1998 (of 4 and 7 months of duration respectively).

Revista Árvore. 2018;42(1):e420110
The diameter of the vessels appeared as a plastic variable against the changes in water availability imposed by the site, while the number of vessels did not. Similar results were found by other authors. For example, in a controlled experiment, Doffo et al. (2017) exposed two Salix clones (clone 13-44 and clone Y: free crossing of $S$. alba) to alternating short periods of flood and drought, and found that the responses at the level of the xylem (vessels and hydraulic conductivity) were dependent on the clone, the type of stress and the temporal sequence of the stress. These authors also showed that the floods imposed less stress than the drought treatment, being the common response the variation in the vessel area. The stress by drought increased the number of vessels and reduced the vessel area, and thus decreased the $\mathrm{Ks}$, the stomatal conductivity and the growth. The stress by flood reduced the vessel area and did not change the number of vessels or Ks. Similarly to that observed in the present study, Doffo et al. (2017) found that clone 13-44 resisted the drought better than clone $\mathrm{Y}$, and that clone $\mathrm{Y}$ was more tolerant to flooding.

The wood density determined in the six Salix clones studied was influenced both by the site and by genetic effects. It is well known that wood density is a character with some degree of genetic determinism. The high heritabilities previously reported for the wood density of willows in the region $(\mathrm{H}=0.65)$ (Monteoliva et al., 2005) could explain the significant differences observed in this study at the clone level. Cerrillo (2014) published results of field studies of different crosses/new clones $(n=68)$ in 10 sites of the Delta of Buenos Aires and Entre Ríos provinces, and recorded the same ranking of clones regarding the wood density regardless of the site.

In the present study, the analysis of the data within each site showed that the clones of site LH (the site with less water excess) presented higher wood density than those of site DM. The correlations showed an inverse relationship between wood density and $\mathrm{Ks}$, although this relationship was obtained only at 7 years of age (Fig. 3). This association makes sense if one considers previously published results which show that higher wood density generates resistance to the water stress by drought by increasing the resistance to the cavitation of the xylem (Wikberg and Ögren, 2004; Doffo et al., 2017). 


\section{Influence of the xylem structural variation on plant growth}

The height and DBH reached by the trees at 13 years of age were different according to the clone and site (Table 1). The American Willow was the clone with lowest growth in both sites. The CAI produced at different ages were also different depending on the site and clone (Fig. 2). In both sites, the highest CAI values were those of trees of 7 years of age (1995), with some exceptions in site DM. These exceptions were the clones less tolerant to floods, such as clones 131-25, 13127, 250-33 and 13-44 (Cerrillo et al., 2013; Laclau et al., 2014; Quiñones, 2017). It should be noted that site DM presented a temporary flood of four months during the fourth year of growth, because, from 1989 to 1995 , the height of the Paraná River was considered highvery high (3.5-5.9 m, Fig. 1) (Baigun et al., 2008; Arredondo, 2009). In site LH, these same four clones achieved the highest CAI values (Fig. 2), showing the best performance in the site without water excess. This increase in basal area at 7 years of age is related to the tendency to produce larger vessel diameters and therefore the possibility of greater theoretical hydraulic conductivity. This association is supported by the positive correlations found between CAI and Ks and between CAI and vessel diameter (with our complete data and discriminated at 7 years of age) (Fig. 3).

\section{Relationships - Interpretation of the differential behaviors of the clones at the two sites studied}

Like clone 26992, the American Willow was found to be tolerant to the floods, at least under the environmental conditions present during the study period. The American Willow responded differently from the other clones, with low growth and high wood density under the different stress situations. This behavior of the American Willow has already been observed in multiple plantation sites (Monteoliva et al., 2005; Cerrillo, 2014; Cerrillo et al., 2014). In contrast, clone 26992 has been found to show low survival, which indicates that it may be susceptible to diseases under prolonged flood conditions, depending on the age at which the stress occurs (Laclau et al., 2014; Quiñones, 2017). Clones 131-25, 131-27, 250-33 and 13-44 tolerated the condition without water excess and with some event of drought in site LH better than the condition of flood in site DM. The sensitivity of clone 13-44 to the floods has already been reported (Cerrillo et al., 2013; Doffo et al., 2017).
The interpretation of the behaviors in response to the sites seems to depend not on the crossing from which they derive, but rather on the clone. This same behavior (clone $\mathrm{x}$ site interaction) has already been cited in Salix by other authors for morphological, anatomical and functional determinations at the level of the whole plant. The adaptations that allow the different clones to respond in a differential way to the abiotic stressors not only occur in the xylem but also at the level of other organs (such as the foliar or root level). These responses were not observed or measured in the present study, but have been observed in several previous studies in willows (Wikberg and Ögren, 2004; Bonosi et al., 2010; Nakai et al., 2010; Doffo et al., 2017).

Some studies regarding these differential behaviors/ adaptations at the clone level have been reported in Argentina. For example, for clone 13-44, Caccia et al. (2014) reported results of studies under controlled conditions of stress by drought and flood at the initial stage of establishment (4 months). These authors found that the measurements of growth (height and DBH) and stomatal conductance of this clone under stress were lower than those of the control, but comparatively better in the treatment of water restriction than in the treatment of partial or total flood. The authors mentioned that this indicates some resistance of clone 13-44 to water deficit, which could be corroborated by the low mortality observed.

Previous studies by Cerrillo (2014) and Cerrillo et al. (2014) have assessed the survival and growth of willows in 10 sites of the Delta (some with flood water permanence for six months, including the summer period) in experiments of 2-5 years with 68 different crossings/new clones, including three of the clones studied in the present study: American, 13-44 and 13127 , as reference controls for the area. The largest average CAI values were obtained by the new clones but without significant differences from clone 13-44. Clone 131-27 presented less growth than the others, being the American Willow the one with worst performance. These authors concluded that two new clones of $S$. matsudana x $S$. alba (Los Arroyos and Agronales) presented different tolerance to prolonged flooding.

\section{CONCLUSIONS}

The results of this study show that the six Salix clones derived from different crossings show differences at the level of the xylem in the structural, functional 
and growth response to the different abiotic stress imposed by the two sites studied, and that these responses depend on the clone, regardless of the crossing.

Among the variables measured, the vessel diameter was the most plastic character compared to the changes in water availability imposed by the site (clone $\mathrm{x}$ site interaction). Wood density also presented variability with the clones, but in general each clone showed similar density at each site.

Our results also showed that, under the environmental conditions of our study period, some of the clones studied, such as the American clone and clone 26992, are better adapted to flood stress, whereas others, such as clones 131-25, 131-27, 250-33 and 1344 , are better adapted to moderate drought conditions, showing different responses at the structural level of the xylem, density and therefore wood production.

\section{ACKNOWLEDGMENTS}

We would like to particularly thank to Ing. Ftal. Fabio Achinelli for sharing his knowledge of willow cultivation. We also thank the Department of Seismology and Weather Information of the School of Astronomical and Geophysical Sciences of the Universidad Nacional de La Plata, Argentina, for providing us with the meteorological data of La Plata. We want to thank Ma. Victoria Gonzalez Eusevi for translating the manuscript.

\section{REFERENCES}

Arredondo F. Histórico: Altura del Río Paraná em el Puerto de Santa Fé 1900-2009 [informe]. Santa Fé: Centro de Estudios y Servicios, Bolsa de Comercio de Santa Fé; 2009.

Baigun CRM, Puig A, Minotti PG, Kandus P, Quintana R, Vicari R, et al. Resource use in the Parana River Delta (Argentina): moving away from an ecohydrological approach?. Ecohydrology and Hydrobiology. 2008;8:245-62.

Barotto AJ, Monteoliva S, Gyenge J, Martinez Meier A, Moreno K, Tesón N, et al. Wood density and anatomy of three Eucalyptus species: implications on hydraulic conductivity. Forest Systems. 2017;26:1-11.

Barros V. Escenarios hidrológicos de caudales medios del río Paraná y Uruguay. Publicación de las Naciones Unidas; 2013. (Serie: Medio Ambiente y Desarrollo, 154).

Bonosi L, Ghelardini L, Weih M. Growth responses of 15 Salix genotypes to temporary water stress are different from the responses to permanent water shortage. Trees. 2010;24:843-54.

Borodowski E, Signorelli A, Batistella A. Salicáceas en el Delta del Paraná: situación actual y perspectivas. In: $4^{\circ}$ Congreso Internacional de Salicáceas en Argentina. La Plata; 2014.

Caccia FD, Guarnaschelli AB, Spinardi J, Vincent P, Garau AM, Fernández Tschieder E, Cerrillo T. Evaluación de algunas respuestas de un nuevo clon de sauce a estrés por inundación. In: $4^{\circ}$ Congreso Internacional de Salicáceas en Argentina. La Plata; 2014.

Cerrillo T, Doffo G, Rodríguez ME, Olguín F, Achinelli F, Luquez V. Tolerancia al anegamiento prolongado de una amplia gama de genotipos mejorados de sauce. In: $4^{\circ}$ Congreso Internacional de Salicáceas en Argentina. La Plata; 2014.

Cerrillo T, Iribarren R, Cobas AC, Monteoliva S. Evaluación xilológica de familias mejoradas de sauces con destino industrial maderero. Revista da Faculdade de Agronomía, La Plata. 2016;115:99-106.

Cerrillo T, Rodriguez ME, Achinelli F, Doffo G, Luquez VMC. Do greenhouse experiments predict willow responses to long-term flooding events in the field? Bosque. 2013;34:71-9, 2013.

Cerrillo T. Selección de seis nuevos clones de sauce (Salix spp) para el Delta del Paraná. In: $4^{\circ}$ Congreso Internacional de Salicáceas en Argentina. La Plata: 2014.

Copini P, den Ouden J, Robert EMR, Tardif JC, Loesberg WA, Goudzwaard L, et al. Flood-Ring formation and root development in response to experimental flooding of young Quercus robur trees. Frontiers in Plant Science. 2016;7:775.

Doffo GM, Monteoliva S, Rodríguez ME, Luquez V. Responses to different combinations of flooding and drought stress episodes in 6 willows (Salix spp.). Canadian Journal of Forest Research. 2017;47:174-82.

Revista Árvore. 2018;42(1):e420110 
Fichot R, Laurans F, Monclus R, Moreau A, Pilate G, Brignolas F. Xylem anatomy correlates with gas exchange, water-use efficiency and growth performance under contrasting water regimes: evidence from Populus deltoides x Populus nigra hybrids. Tree Physiology. 2009;29(12):1537-49.

García M, Basile P, Riccardi G. Estudio de registros de caudales y niveles hidrométricos para grandes crecidas sobre Tramo del Río Paraná. In: $23^{\circ}$ Congreso Nacional del Agua. Resistencia, Argentina; 2011.

Laclau P, Gyenge J, Fernandez ME, Dominguez Daguer D, Villaverde R, et al. Supervivencia inicial de clones de sauce en suelos hidrohalomórficos de la depresión del salado. In: $4^{\circ}$ Congreso Internacional de Salicáceas en Argentina. La Plata: 2014.

Levy PE, Mckay HM. Assesing tree seedling vitaly tests using sensivity analysis of a processbased growth model. Forest Ecology and Management. 2003;183:77-93.

Monteoliva S, Cerrillo T. Densidad y anatomía de la madera en familias mejoradas de sauces en Argentina. Revista Arvore. 2013;37:1183-91.

Monteoliva S, Marlats R. Efecto del sitio, clon y edad sobre el crecimiento y la calidad de madera en sauces de corta rotación. Revista Investigación Agraria, Sistema y Recursos Forestales. 2007;16:15-24.

Monteoliva S, Senisterra MG, Marlats R. Variation of wood density and fibre length in six willow clones (Salix spp.). IAWA J. 2005;26:197-202.

Monteoliva S, Senisterra MG. Efecto del sitio, el origen y el clon sobre el crecimiento y propiedades de la madera de Populus. Revista de Investigación Agraria, Sistema y Recursos Forestales. 2008;17:261-270.

Nakai A, Yurugi Y, Kisanuki H. Stress responses in Salix gracilistyla cuttings subjected to repetitive alternate flooding and drought. Trees. 2010;24:1087-95.

Quiñones A, Gyenge J, Fernandez M.E. Morphophysiological response to vertically

heterogeneous soil salinity of two glycophyte woody taxa, Salix matsudana $x$ S. alba and Eucalyptus camaldulensis Dehnh. Plant and Soil. 2017:416.

Quiñones, A. Respuestas morfo-fisiológicas de especies leñosas a condiciones ambientales de estrés múltiple: una contribución al desarrollo de plantaciones forestales en la Pampa

Deprimida. [tesis]. Mar del Plata: Universidad Nacional de Mar del Plata; 2017.

Schreiber SG, Hacke UG, Hamann A, Thomas BR. Genetic variation of hydraulic and wood anatomical traits in hybrid poplar and trembling aspen. New Phytologist. 2011;190:150-60.

Villalba R, Lara A, Masiokas M, Urrutia R, Luckman BH, Marshall GJ. Unusual Southern Hemisphere tree growth patterns induced by changes in the Southern Annular Mode. Nature Geoscience. 2012;5:793-8.

Walker JFC. Primary wood processing. Principles and practice. Amsterdã: Spinger; 2006.

Wikberg J, Ogren E. Interrelationships between water use and growth traits in biomass-producing willows. Trees. 2004;18:70-6.

Zanne AE, Westoby M, Falster DS, Ackerly DD, Loarie SR, Arnold SEJ, et al. Angiosperm wood structure: global patterns in vessel anatomy and their relation to wood density and potential conductivity. American Journal of Botany. 2010;97:207-15.

Ziemiñska K, Westoby M, Wright I.J. Broad anatomical variation within a narrow wood density range - a study of twig wood across 69 Australian Angiosperms. PLoS ONE. 2015;10(4):e0139496. 